\title{
Studies on the mouldability of structural foams in hybrid moulds
}

\author{
Nogueira, A.A. ${ }^{a}$, Gago, P.T. ${ }^{b}$, Martinho, P.G. ${ }^{c, e}$, Brito, A.M. ${ }^{d}$, Pouzada, A.S. ${ }^{\text {e, }}$ \\ ${ }^{a}$ Vangest Group, Marinha Grande, Portugal \\ bDTech, Lda, Marinha Grande, Portugal \\ 'Polytechnic Institute of Leiria, School of Technology and Management, Leiria, Portugal \\ ${ }^{d}$ Dep. Polymer Engineering, University of Minho, Guimarães, Portugal \\ e Institute for Polymer and Composites/I3N, University of Minho, Guimarães, Portugal
}

\begin{abstract}
A B S T R A C T
In the context of the research project Hybridmould 21, studies on the mouldability of structural foams using hybrid moulds have been carried out. Hybrid injection moulds are considered as an alternative for prototype series or short production runs of large parts. In hybrid moulds the moulding elements (blocks or other inserts) are manufactured in alternative metallic materials or synthetic materials typically using in rapid prototyping. Thermoplastic structural foams are moulded by injection moulding using injection pressures lower than in than in conventional injection moulding. The structural foam results from a dispersed gaseous phase, which derives from the expansion of a chemical blowing agent usually compounded in a masterbatch. In this project, thermoplastics and thermosets were used (PP, ABS and PUR) using a hybrid mould instrumented for temperature, pressure and expansion force. The moulding block was manufactured by vacuum casting of an epoxy composite. In this paper are mainly discussed the results obtained on liquid injection moulding polyurethane resins in the hybrid mould.
\end{abstract}

\author{
ARTICLE INFO \\ Keywords: \\ Hybrid moulds \\ Structural foams \\ Rapid prototyping techniques \\ Low pressure injection moulding \\ Reaction injection mould \\ ${ }^{*}$ Corresponding author: \\ asp@dep.uminho.pt \\ (Pouzada, A.S.)
}

\section{References}

[1] Martinho, P.G., Bártolo, P.J., Queirós, M.P., Pontes, A.J., Pouzada, A.S. (2005). Hybrid moulds: the use of combined techniques for the rapid manufacturing of injection moulds, In: P.J. Bártolo (ed.), Proceeding of $2^{\text {nd }}$ International Conference on Advanced Research in Virtual and Rapid Prototyping, 421, London, Taylor and Francis.

[2] Oliveira, V., Pouzada, A.S. (2001). Desenvolvimento e Engenharia de Produto - Factor chave de competitividade, O Molde, Vol. 50, 6-10.

[3] Pontes, A.J., Queirós, M.P., Martinho, P.G., Bártolo, P.J., Pouzada, A.S. (2010). Experimental assessment of hybrid mould performance, The International Journal of Advanced Manufacturing Technology, Vol. 50, No. 5, 441-448.

[4] Dunne, P., Soe, S.P., Byrne, G., Venus, A., Wheatley, A.R. (2004). Some demands on rapid prototypes used as master patterns in rapid tooling for injection moulding, Journal of Materials Processing Technology, Volume 150, No. 3, 201-207.

[5] Canevarolo Jr., S.V. (2004). Técnicas de Caracterização de Polímeros, Artliber, São Paulo, 430.

[6] Pontes, A.J., Queirós, M., Bártolo, P.J., Pouzada, A.S. (2005). A study on design and performance of hybrid moulds for injection moulding, In: Conference Proceedings - ICIT 2005, $5^{\text {th }}$ International Conference on Industrial Tools, Celje, Slovenia.

[7] Vasconcelos, P.V., Jorge Lino, F., Neto, R.J., Paiva, R. (2006). Design epoxy resins based composites for rapid tooling applications, In: Proceedings of $5^{\text {th }}$ International Conference on Mechanics and Materials in Design, Porto, Portugal, 487-488.

[8] Bareta, D.R., Zeilmann, R.P., Costa, C.A., Pouzada, A.S. (2006). Application of alternative materials in hybrid mould cores, In: Proceedings RPD 2006 - Building the Future by Innovation, Marinha Grande, Portugal. 
[9] Pouzada, A.S. (2009). Hybrid moulds: a case of integration of alternative materials and rapid prototyping for tooling, Virtual and Physical Prototyping, Vol. 4, No. 4, 195-202.

[10] Martinho, P.G., Cardon, L., Neves, T., Bartolo, P.J., Pouzada, A.S. (2008). On the influence of the materials used on the moulding blocks of hybrid moulds, In: Proceedings of PMI 2008 - International Conference on Polymers \& Moulds Innovations, Ghent, Belgium.

[11] Martinho, P.G., Cardon, L., Neves, T., Bártolo, P.J., Pouzada, A.S. (2008). A study of the ejection forces on moulding inserts obtained by RPT techniques, In: Proceedings of RPD 2008 - Designing the Industry of the Future, Oliveira de Azeméis, Portugal.

[12] Kamal, M.R., Isayev, A.I., Liu, S.-J. (2009). Injection molding: Technology and fundamentals, Munich, Hanser.

[13] Lanz, R.W., Melkote, S.N., Kotnis, M.A. (2002). Machinability of rapid tooling composite board, Journal of Materials Processing Technology, Vol. 127, No. 2, 242-245.

[14] Malloy, R.A. (1994). Plastic part design for injection molding: An introduction, New York, Hanser.

[15] Park, Y., Colton, J.S. (2003). Sheet metal forming using polymer composite rapid prototype tooling, Journal of Engineering Materials and Technology, Vol. 125, 247-255.

[16] Tomori, T., Melkote, S., Kotnis, M. (2004). Injection mold performance of machined ceramic filled epoxy tooling boards, Journal of Materials Processing Technology, Vol. 145, No. 1, 126-133.

[17] Wohlers, T., Grimm, T. (2003). Is CNC machining really better than RP?, Gardner Publications, from http://learn.lboro.ac.uk/ludata/cd/cad/rp_v_cnc.pdf, accessed June 20, 2012.

[18] Esteves, F.R., Pouzada, A.S., Martins, C.I. (2011). Formulation and characterization of polypropylene structural foam for large parts, In: Proceedings of $6^{\text {th }}$ International Materials Symposium MATERIAIS 2011, Guimarães, Portugal.

[19] Gonçalves, M.W., Salmoria, G.V., Ahrens, C.H., Pouzada, A.S. (2007). Study of tribological properties of moulds obtained by stereolithography, Virtual and Physical Prototyping, Vol. 2, No. 1, 29-36. 